\title{
Effects of Occupational Safety and Health Hazards' Exposure on Work Environment in the Water Service Industry within Kisumu County - Kenya
}

\author{
${ }^{1}$ Ibrahim Oluoch, ${ }^{2}$ Paul Njogu, ${ }^{3}$ Jared O. H. Ndeda \\ ${ }^{1 \& 2}$ Institute of Energy and Environmental Technology, Jomo Kenyatta University of Agriculture and Technology \\ (JKUAT) P. O. Box 62000-00200 NAIROBI-KENYA \\ ${ }^{3}$ Physics Department, Jomo Kenyatta University of Agriculture and Technology (JKUAT), P.O.Box \\ 62000-00200 NAIROBI-KENYA
}

\begin{abstract}
The study sought to determine effects of exposure to occupational safety and health hazards on work environment in the Kenyan Kisumu County Water Service industry. The study utilized a descriptive research design. The target population consisted of employees of Kisumu Water and Sewerage Company (KIWASCO) and Lake Victoria South Water Service Board (LVSWSB) working in water treatment works, waste water treatment plants and construction sites. Questionnaires were used to obtain primary data; that were analyzed using quantitative techniques. Standard deviation was adapted to measure disparity for the likert-scale questionnaires. The entire hypothesis was tested at $95 \%$ confidence level. Risk Severity rating was then done for Biological, Chemical, Ergonomics, Physical, Psychological and Safety risks. Results reveal that employees working in the water service industry in Kisumu County are exposed to hazards and risks. Both Biological and Chemical risks are high or major among staff in the water sector. While Ergonomics, Physical and Psychological risks are minor, they are likely to happen in the sector. We recommend that the management of water service industry immediately institute measures to avoid the Biological and Chemical risks, while adequate preparedness should be put in place against other risks.
\end{abstract}

Keywords: Occupational health, safety, exposure, Hazards, water service industry, work environment

\subsection{Background}

\section{Introduction}

The health of adults of working age affects economic and social development. Recent occupational health data indicate that $40 \%-50 \%$, of the world population is exposed to hazardous conditions in the workplace. It is estimated that approximately 120 million occupational accidents occur worldwide each year, with 200,000 fatalities. Each year between 68 million and 157 million new cases of occupational diseases arise as a consequence of various types of work-related exposures. In addition, approximately $30 \%-50 \%$ of workers in industrialized countries experience psychological stress. Environmental stressors such as hazardous conditions are one cause, but occupational stress results from work organization (e.g. workload, lack of autonomy and control over work, shift work, wage scales and routine, repetitive work). Stress associated with work organization has been shown to contribute to cardiovascular disease, muscular skeletal problems and other conditions. Other than the transfer of unsafe technologies, the changing nature of work will have a dramatic impact on worker's health. Technological innovations will result in job losses, replacement of full time work and part-time work, more work in the informal sector and self-employment.

Unfortunately, only 5\%-10\% of workers in developing countries and $20 \%-50 \%$ of workers in industrialized countries have access to adequate occupational health services. In many countries there are neither the resources nor the control of occupational hazards. Healthy workers are more likely to be productive workers, who are essential for successful business and lay the foundation for a prosperous economy and sustainable development.

The healthy workplace concept provides a valuable tool for developing or reinforcing occupational health and health standards so that conditions continuously improve for the working population. However, a healthy workplace is not only free of hazards, but also provides an environment that is stimulating and satisfying for those who work there. The healthy organization acknowledges all the elements of occupational health and safety in developing policies and programs for the wellbeing of its workers (WHO, 1999).

Abraham Maslow in the hierarchy of needs theory on human motivation used the terms Physiological, Safety, Belongingness and love, Esteem, Self-Actualization and Self -Transcendence needs to describe the patterns that human motivations generally move through. This study employs the theory of hierarchy of needs on Safety. Safety at work ranks as an important factor in job satisfaction (Kreitner, 2007; Thobora \& Thuita, 2015). 
It is argued that there is been low compliance to health and safety regulations; where the level of regulation and enforcement of occupational health and safety is grossly inadequate especially when compared to developed countries (Rotich \& Kwasira, 2015). During worker's time he / she is exposed to various hazards including accidents, noise, dust, vibrations, heat and harsh chemicals among others (Nzuve \& Ayub, 2012).

\subsubsection{The occupational Health and Safety Act 2007}

The occupational Safety and Health Act 2007 aims at securing the safety, health and welfare of workers and the protection of persons other than the workers against the risk to safety and health arising out of, or in connection with the activities of persons at work. The Act sets objectives to promote and improve occupational safety and health standards.

The OSH services in Kenya are governed by two pieces of legislation: the Occupational Safety and Health Act (OSHA), 2007 and the Work Injury Benefits Act (WIBA), 2007. The purpose of OSHA, 2007 is to secure the safety, health and welfare of people at work, and to protect those not at work from risks to their safety and health arising from, or in connection with, the activities of people at work. The purpose of WIBA, 2007 is to provide compensation to employees for work-related injuries and diseases contracted in the course of their employment, and for connected purposes. Nyakang'o (2016) confirms that more than half of the industrial accidents and injuries in Kenya go unreported. The report estimates that occupational health and safety fatalities and injuries in Kenya for the last five years 2000-2004 are: 1528, 1923, 1332, 1599 and 1387, this was viewed from the background that 11,387 factories and other places of work are registered by the Department of Health and Safety. The report observed that in 2003, mining, construction and transport accounted for $41 \%$ of accidents in Kenya, machine operators and assemblers $28 \%$ while other occupations share $31 \%$ of workplace accidents. From this detail, in relation to age groups $44.4 \%$ of the injuries occurred to persons in the age group of 20 to 29 years, $25 \%$ to the age group of 30 to 39 years and $24 \%$ to the age below 20 years.

According to Manduku and Munjiri (2017), a closer scrutiny of the OSHA, 2007 reveals that many of the dangerous occurrences and prescribed occupational diseases in the $1^{\text {st }}$ and $2^{\text {nd }}$ schedules may exist. There are several instances of unsafe working conditions and work behavior that both employees and employer should place emphasis on. Assets development and operations of water and sanitation facilities are risky assignments for contractors and operators. Health and safety of employees at the workplace in the water industry cannot be underestimated in the wake of increasing risks in sensitive service industries.

In the wake of upcoming technology, social conflicts and terrorism; water infrastructure facilities remain vulnerable and easy points of access to implement acts of terror. Despite the role played by these workers in national development, they are exposed to life threatening challenges like poor working conditions/ environments which may lead to safety and health problems. There is need to establish level of awareness, nature of hazards as practices that influence workplace health and safety in both construction and operations of facilities. This study therefore sought to assess the influence and practices of occupational health and safety in water service industry.

According to Vesely et al., (1981), the SPE Risk Assessment Model worksheet assesses risks for specific hazards by determining risk as a function of Severity, Probability and Exposure. Risk $=\mathrm{f}(\mathrm{SPE})$

Severity is rated between 1-5 thus: $1=$ None or Slight; $2=$ Minimal; $3=$ Significant; $4=$ Major; $5=$ Catastrophic Probability is also rated from 1-5 thus; $1=$ Impossible; $2=$ Unlikely in normal circumstances; $3=50 \% ; 4=$ Greater than $50 \% ; 5=$ Vey likely

Exposure is rated from 1-4 thus; $1=$ None; $2=$ Average; $3=$ Above average; $4=$ Great.

\section{Methodology}

The study utilized a descriptive survey research design. The target populations for this study were 80 number staff working in the waste water treatment, waste water treatment and new project construction sites of LVSWSB and KIWASCO Limited. The study used questionnaires and observation. The study used questionnaire, interviews and observation to obtain primary data. Data was analyzed using quantitative techniques. Standard deviation to measure response disparity for the Likert -scale question items was also adapted. The entire hypothesis was tested at $95 \%$ confidence level. Descriptive statistics such as frequencies, percentages, mean and standard deviation were used to describe the characteristics of collected data.

\section{Data Analysis And Findings}

This section presents the descriptive results on history of accidents and injuries, existing risks and hazards, the current impacts and the current risks levels in the work environment in the water industry.

\subsection{Demographic Information}

This section analyses, presents and interprets the results findings on the respondents' work organization, ages, gender, highest educational level, duration worked for their corporations and the nature of their work. The results are discussed under results and discussions. 
Table 3.1: Demographic Information

\begin{tabular}{|l|l|r|}
\hline Characteristics & Categories & Percentage/Proportion \\
\hline Respondents organization & LVSWSB & $12(15.79 \%)$ \\
\hline & KIWASCO & $57(75.00 \%)$ \\
\hline & GULF & $7(9.21 \%)$ \\
\hline Gender of the respondent & Male & $61(80.3 \%)$ \\
\hline & Female & $15(19.7 \%)$ \\
\hline Age of the respondent & $18-28$ & $24(31.6 \%)$ \\
\hline & $29-39$ & $28(36.8 \%)$ \\
\hline & $40-50$ & $24(31.6 \%)$ \\
\hline Respondents Highest level of education & Primary & $6(7.9 \%)$ \\
\hline & Secondary & $9(11.8 \%)$ \\
\hline & College & $61(80.3 \%)$ \\
\hline Duration worked with organization & One year & $24(31.6 \%)$ \\
\hline & Two years & $10(13.2 \%)$ \\
\hline & Three years & $15(19.7 \%)$ \\
\hline & Four years & $27(35.5 \%)$ \\
\hline Nature of respondents work & Construction & $14(18.4 \%)$ \\
\hline & Water supply & $49(64.5 \%)$ \\
\hline & Waste water & $13(17.1 \%)$ \\
\hline
\end{tabular}

Table 3.2: Occupational Safety and health hazards and risk exposure and work environment water service industry in Kisumu County

\begin{tabular}{|c|c|c|c|c|c|}
\hline Statements & SD & $\begin{array}{l}\mathrm{D} \\
(\%)\end{array}$ & $\begin{array}{l}\mathbf{N} \\
(\%)\end{array}$ & $\begin{array}{l}\mathbf{A} \\
(\%)\end{array}$ & $\begin{array}{l}\mathrm{SA} \\
(\%)\end{array}$ \\
\hline I have had any previous accidents or injuries in the workplace & $34.2 \%$ & $15.8 \%$ & $7.9 \%$ & $30.3 \%$ & $11.8 \%$ \\
\hline I have experienced any trauma in the workplace & $26.3 \%$ & $31.6 \%$ & $14.5 \%$ & $21.1 \%$ & $6.6 \%$ \\
\hline I have had a change in the way my body functions, grows or develops & $25.0 \%$ & $121.1 \%$ & $122.4 \%$ & $21.1 \%$ & $10.5 \%$ \\
\hline $\begin{array}{l}\text { I have had a change in mental condition resulting from stress, } \\
\text { traumatic experience or exposure to solvents }\end{array}$ & $22.4 \%$ & $32.9 \%$ & $18.4 \%$ & $11.8 \%$ & $14.5 \%$ \\
\hline $\begin{array}{l}\text { There is a risk of an object falling from a height(potential or } \\
\text { gravitational energy) }\end{array}$ & $32.9 \%$ & $21.1 \%$ & $6.6 \%$ & $22.4 \%$ & $17.1 \%$ \\
\hline $\begin{array}{l}\text { There is a risk of a run-away chemical reaction or a release of } \\
\text { compressed gas or steam }\end{array}$ & $15.8 \%$ & $28.9 \%$ & $15.8 \%$ & $17.1 \%$ & $22.4 \%$ \\
\hline $\begin{array}{l}\text { Exposure to hazards in the workplace always causes injury, illness or } \\
\text { other adverse health effects in the workplace. }\end{array}$ & $5.3 \%$ & $11.8 \%$ & $3.9 \%$ & $32.9 \%$ & $46.1 \%$ \\
\hline There is inadequate or poor lighting at the workplace & $31.6 \%$ & $31.6 \%$ & $9.2 \%$ & $14.5 \%$ & $13.2 \%$ \\
\hline $\begin{array}{l}\text { There is a likelihood that the injury, disease or damage is resulting } \\
\text { from exposure to a hazardous condition at the workplace }\end{array}$ & $10.5 \%$ & $23.7 \%$ & $23.7 \%$ & $21.1 \%$ & $21.1 \%$ \\
\hline
\end{tabular}

The respondents were asked to state the types of hazards they are exposed to at the workplace. The results shown in table below.

Table 3.3: Types of hazards exposed to at the workplace

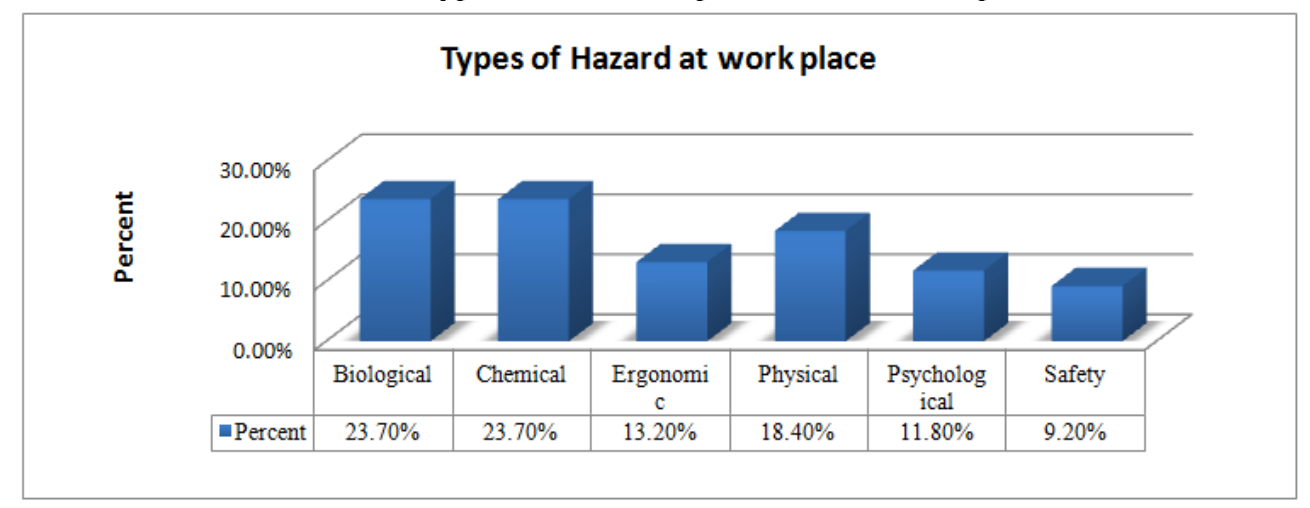

Table 3.4: Relationship between exposure to hazards and risks, and work environment

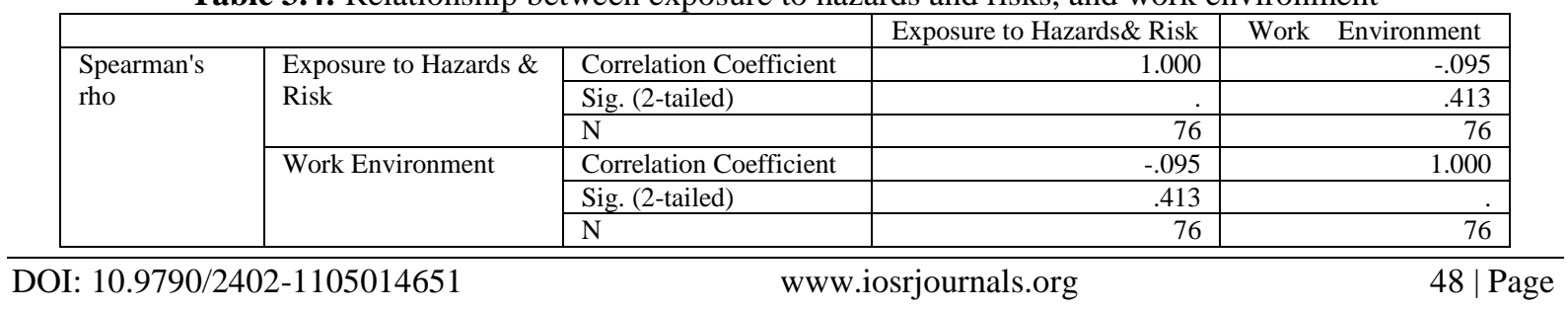


It was established that there is an insignificant weak negative relationship between exposure to hazards and risks and work environment. This meant that if the exposure to hazards and risks are reduced then the work environment would improve. Ng'ang'a and others (2013) explains the indirect proportionality, that there are aspects of work environment that have the potential of causing immediate and sometimes violent harm to a worker hence affecting performance; these include poorly maintained equipments, unsafe machineries, and exposure to hazardous chemicals among others.

Table 3.5: Water Sector Risk Severity Rating

\begin{tabular}{|l|l|l|l|l|l|}
\hline Risk & Severity & Probability & Exposure & SPE Value & Remarks \& Guidance \\
\hline Biological & 5 & 3 & 4 & 60 & High Risk- Correct Immediately \\
\hline Chemical & 5 & 3 & 4 & 60 & High Risk- Correct Immediately \\
\hline Ergonomics & 3 & 3 & 4 & 36 & Possible Risk- Needs attention in the near future \\
\hline Physical & 3 & 3 & 4 & 36 & Possible Risk- Needs attention in the near future \\
\hline Psychological & 3 & 3 & 4 & 36 & Possible Risk- Needs attention in the near future \\
\hline Safety & 3 & 3 & 4 & 36 & Possible Risk- Needs attention in the near future \\
\hline
\end{tabular}

\section{Results And Discussion}

\subsection{Hazards and risk exposure}

Majority of the respondents at 38(50\%) stated that they had no previous accidents or injuries in the workplace, 32(42.1\%) stated that they had previous accidents or injuries in the workplace while the minority at $6(7.9 \%)$ were undecided. A similar study conducted by Ng'ang'a et al., (2013), revealed that the construction industry's appalling health and safety record is a worldwide problem affecting both the developed and developing countries. Very few statistics though exist on the nature of accidents and injuries affecting workers in developing countries primarily due to the poor or nonexistence of regulatory framework. However, health and safety data collected in developed countries show a consistent pattern for worker fatalities and injuries. As the nature of construction works is similar in both developed and developing countries, the problems reported in the industrialized world do not appear particularly "high tech". As the data from developing countries are so scarce it would appear reasonable to assume that the types of fatalities and injuries are similar worldwide.

It was popular among 44(57.9\%) not to have experienced any trauma in the workplace, $21(27.7 \%)$ had experienced while 11(14.5\%) were not certain whether they had experienced any trauma in the workplace or not. Majority of the respondents at $35(46.1 \%$ ) did not experience a change in the way their body functions, grows or develops, $24(31.6 \%)$ had while the minority at $17(22.4 \%)$ were unsure whether they had a change in the way their body functions, grows or develops or not. More than one half of the respondents at $42(55.3 \%)$ had not experienced a change in mental condition resulting from stress, traumatic experience or exposure to solvents, 20(26.3\%) had experienced a change in mental condition resulting from stress, traumatic experience or exposure to solvents with the minority at 14(18.4\%) were undecided.

More than one half of the respondents at $41(54 \%)$ stated that there was no risk of an object falling from a height (potential or gravitational energy), 30(39.5\%) stated that there was a risk of an object falling from a height with the least number of respondents at 5(6.6\%) were undecided. Less than one half of the respondents at $34(44.7 \%)$ said that there was no risk of a run-away chemical reaction or a release of compressed gas or steam, $30(39.5 \%)$ stated that the risk was present while the least number of respondents at $12(15.8 \%)$ were unsure. It was revealed from a similar study according to Ng'ang'a et al., (2013), that waste water may contain potentially hazardous chemicals depending on the source of water quality, drinking water treatment processes and industries discharging to the sewer, including chlorinated organic solvents and pesticides, Polychlorobenzene (PCB), polycyclic aromatics, petroleum hydrocarbons, flame retardants, nitrosamines, heavy metals, asbestos, dioxins and radioactive materials.

Majority of the respondents at 60(79\%) said that exposure to hazards in the workplace always caused injury, illness or other adverse health effects in the workplace, 13(17.1\%) stated that exposure to hazards in the workplace always caused injury, illness or other adverse health effects in the workplace while minority at $3(3.9 \%)$ were unsure. This study findings was largely supported by a similar study carried out by Ng'ang'a et al., (2013), that established that there are aspects of work environment that have the potential of causing immediate and sometimes violent harm to a worker including poorly maintained equipments, unsafe machineries, and exposure to hazardous chemicals among others. Potential injuries include loss of hearing, eye sight or body like cuts, burns, bruises, broken bones and electric shock. More than one half of the respondents at $48(63.2 \%)$ stated that there was adequate and good lighting at the workplace, 21(27.7\%) noted that it was inadequate or poor lighting while the minority at 7(9.2\%) were unsure.

Most of the respondents at 32(42.2\%) stated that there was a likelihood that the injury, disease or damage was resulting from exposure to a hazardous condition at the workplace, 26(34.2\%) had divergent opinion while $18(23.7 \%$ ) were undecided. A related study supported this finding by establishing that the types and frequencies of injuries that occur to construction workers do vary according to the tasks that they carry out 
such as falls, overexertion or strenuous movement, handling falling or flying objects, contacts with stationery objects (Missed steps), contact with moving objects, contact with heat or cold, contact with chemicals, exposure to electricity, fire, explosions or blasts (Larcher et al., 1999)

\subsection{Hazards exposure at the workplace}

In this study Severity of the risks identified between significant (3) to catastrophic (5), Probability is categorized as 50-50 (3) since they are likely to happen, while Exposure is Great (4) due to day to day interactions with the identified risks. Risks have been rated by SPE Risk Assessment Model worksheet and categorized as high at 60 for Biological and chemical hazards, while Ergonomics, Physical and Psychological are rated as possible risks at 36 .

\subsection{Work environment}

The study analyzed the relationship between exposure to hazards and risks and work environment. It was established that there is an insignificant weak negative relationship between exposure to hazards and risks and work environment. This meant that if the exposure to hazards and risks are reduced then the work environment conditions would improve.

\section{V. onclusion}

The employees working in the water service industry in Kisumu County were exposed to hazards and risks. Both Biological and Chemical risks are high or major in the water sector; while Ergonomics, Physical, Psychological risks are minor but are likely to happen. It was inferred that there is a relationship between exposure to hazards and risks, and work environment: If the exposure to hazards and risks are reduced then the work environment would improve.

\section{Recommendations}

i. The management of water service industry should give urgent and immediate attention to Biological and Chemical risks, while other risks should not be ignored in the near future.

ii. The management of the water service industry should ensure that staffs are sensitized further on occupational safety and health. This will enhance the knowledge of all of them in various aspects and ultimately lead to improved work environment.

iii. The management of the water service industry should ensure that all the aspects of Safety and Health Act of 2007 is implemented, especially training on occupational health and safety at the workplace.

iv. Further studies to establish the impact of the current biological and chemical risks among staff in the water sector industry.

\section{References}

[1]. Antonsen, S., Safety Culture: theory, method and improvement, Ashgate Pub Co, Uk, 2009,172

[2]. Australian Safety and Compensation Council, National Code of Practice for Induction for Construction Work, 2007.

[3]. Bandura,A (1989) Social Cognitive Theory. In R Vasta (Ed) Annals of Child Development. Vol. 6. Six theories of Child Development (pp.1-60). Greenwich, CT JAI Press.

[4]. Campbell, A ; All Signs Point to Yes; Literacy's Impact on Workplace Health and Safety, Ottawa; The Conference Board of Canada. 2008.

[5]. European Agency for Safety and Health at Work. Annual Report 2007. Available online at htt://osha.europa.eu

[6]. Economic Survey 2011, Kenya National Bureau of Statistics. Available online at http:// www.knbs.or.ke

[7]. ILO Conventions. Available online at http://www.ilo.org

[8]. ILO, (2013). National Profile on Occupational Safety and Health - Kenya

[9]. ILO Code of Practice on Recording and Notification of Occupational Accidents and Diseases (ILO, Geneva, 1996): Available online at http://www.ilo.org

[10]. International Corporation Finance, Environmental, Health, and Safety Guidelines for Water and Sanitation, 2007.

[11]. James. L,. Choi, C., Ko C., McNeil, K., Minton, K., Wright, A., \& Kim, K. (2008). Organizational and psychosocial climate: A review of theory and research. European Journal of Work and Organizational Psychology, 17, 5-32.

[12]. Katsuro, P., Gadzirayi, C. T., Taruwona M \& Mupararano, S. (2010). Impact of Occupational Health and Safety on Worker Productivity; A case of Zimbabwe Food Industry. African Journal of Business Management Volume 4 (13), pp. 2644-2651, 4 October 2010. Available online at http://www.academicjournals.org/AJBM.

[13]. Kenya National Bureau of Statistics (2010). The 2009 Kenya Population and Housing Census, Volume 1C.

[14]. Kothari, C. R., (2004). Research methodology. Methods and techniques. (2nd ed). New Delhi: New Age International Publishers.

[15]. Kreitner, R. (2007). Management. (10 $10^{\text {th }}$ ed.) Boston: Houghton Mifflin company

[16]. Larcher P \& Sohail M. (1999). Review of Safety in Construction and Operation for the WS\&S Sector: Part 1, London School of Hygiene \& Tropical Medicine, UK WEDC, Loughborough University, UK.

[17]. Laws of Kenya, Kenya Law Reports. Available online at http://www.kenyalaw.org

[18]. Law, R., Dollard, M., Tuckey,R., \& Dormann, C. (2011). Psychosocial safety climate as a lead indicator of workplace bullying and harassment, job resources, psychological health and employee engagement. Acid. Anal. Prev, 1-12.

[19]. Manduku, M.F., Munjuri, M. (2017). Extent of the Implementation of the Occupational Safety and Health Act 2007 in the Sarova Group of Hotels in Nairobi; International Journal Of History And Research Volume 1, Issue 1, pp 1-17, 2017.

[20]. Maslow, A., Lowry, R., \& Maslow, B. (1979). The Journal of A. H. Maslow. California: Brooks/Cole. 
[21]. Mayhew, C., \& Quinlan, M. (2002). Fordism in the Fast Food Industry; Pervasive Management Control and Occupational Health and Safety Risks for Young temporary workers; Blackwell Publishers Ltd / Editional Board 2002 pp 262-284.

[22]. Mugenda, O. M. and Mugenda, A. G. (2003).Research Methods: Quantitative and Qualitative Approaches, Acts Press, Nairobi, Kenya

[23]. Ng'ang'a, K., Ngigi P., Siboe I., Ongundo D., Wanyona G.,(2013); Health and Safety Conditions at Construction sites in Nairobi County, Kenya.(pp. 336-342).

[24]. Nyakong'o, J.B. (2016).Summary Status of Occupational Health And Safety in Kenya. Workshop on the IUPAC-UNIDO Safety Training Program, Part of the IUPAC Congress in Bejing, on Wednesday, August 17

[25]. Nzuve, M. \& Ayubu, B. (2012). The Extent of Compliance with Occupational Safety and Health Regulations at Registered Workplaces in Nairobi. International Journal of Business, Humanities and Technology Vol.2 No.2: (pp 115-119).

[26]. Occupational Safety and Health Act, 2007. Kenya Gazette Supplement. No 111(Acts No. 15). Available online at http://www.kenyalaw.org

[27]. Rotich, L., Kwasira, J. (2015). Assessment of Success Factors in the Implementation of Occupational Health and Safety Programs in Tea Firms in Kenya: A Case of Kaisugu Tea Factory, International Journal of Economics, Commerce and Management Vol. III, Issue 5, May 2015, (pp. 797-811).

[28]. Iavicoli S, Rondinone B, Marinaccio A, Fingerhut M, (2005).Research Priorities in Occupational Safety and Health; A review Article; Industrial Health 2006, 44, 169-178.

[29]. Thobora, P., Thuita, S (2015). Assessing the Level of Compliance of Occupational Safety and Health Risk Management Practices with Occupational Safety Legislation in Public TVET Institutions in Nairobi, Kenya, Researchjournalis Journal of Industrial Engineering Vol.1 No.1 May 2015.

[30]. Vesely, W.E, Goldberg, F.F, Roberts, H.H, Haasl, R.F. (1981) Fault Tree Hand book. Systems and Reliability Research Office of U.S Nuclear Regulatory Commission, Washington D.C 20555

[31]. Wallerstein, N; \& Weinger, M. (1992). Health and Safety Education for Worker Empowerment. American Journal of Industrial Medicine 22: 619-635.

[32]. WASREB (2015), Impact Report; Performance Review of Kenya's Water Services Sector 2013-2014, Issue No. 8

[33]. Wikipedia, available on http://en.wikipedia.org/wiki/Chernobyl_disaster.

[34]. Work Safe NB, Health \& Safety Orientation Guide for Employees, 2014.

[35]. Work Safe Victoria, Controlling OHS Hazards and Risk. A handbook for workplaces, Edition No.1, November 2007.

[36]. World Health Organization. (1999). Regional Guidelines for the Development of Healthy Workplaces. 